断篔装置の性格上，管電厓と曝射時間は限定される： 理想的には管電流を变化させながら濃度調整を行えば表 面線量は指数関数的に減少するが，今回の奏験では機 構的に不可能であった。従ってファントム上に置いた MixDの擪さを変化させて濃度調整を行った。 その際我 我はMixDの人射線量を表面線量として求めた為に，実 験の様な誤差が生じた。本来は M 1 D の透過線量を求 めるべきであった，次国ばこの様な誤りがない様に更に 検討を加えたい.

\section{8. 吸気同調小児撮影の考案}

佐賀県立病院放射線科 宮崎 安笑・O北島 仁治

[目的]

乳児胸部単維撮影において重要なしとは心臓の形体縦 隔洞，肺紋理. 横隔膜などが診断の対象として見られま す.そして常に吸気の状態で撮影されている事が望まし い訳です。.そこで我々は最も簡単な方法で又市販品に比 べ安洒にしかも簡便に製作できるものを試作しました.

[方法]

小㫛撮影台上に臥位にした幼照胸壁側面に棒の先端に マイクロスイッチを取付けた反対側を台上に固定した接 触子を奻児の吸気時て動作させX線を曝射する方法です。

〔結果〕

昅気の状態で写真を撮る事が本装置を使用すれば確実 でしか6安価である。文時間的手数がかかるのは他の製 品之同じである.

\section{質問}

呼吸同調装置はずでにいろいろと市販されたすのがあ るが，今度考案さ机た装置は前者の装置にくらべてどの ような特徽があるのか。

田中：高生（福岡）

\section{追加。}

臥位での固定器具を使用されているが，立位での固定 具及び呼吸同調装置を考えるとむつと效果が上るものと 思われる．介添者による固定より固定具だりでの固定が 望ましい: 我々のところでは立位固定具及び鼻呼吸同調 装置を利用している.

田中 高生（福䬖）

答

1.乙の度の装置は手製であることにより製作原佰が 非常に安価飞出来る事加特徽だと思います。

2、呼吸の動きを利用した点は市販のもの之変わりま せんがマイクロスイッチを棒の先端任取付けットする だけの簡便な方法が違っている点だと思います。

3. 小览撮影は立位で撮るのが大方の常識だと思われ るので立位撮影台ととむに今後検討すべき事と思われま
ఫे.

4. 小児撮影台呼吸同調装置はその手数のわずらわし さと効果加らして絶対的なものはなく多様な製品が販売 されているのが現状と思います。

\section{XTV 自動制御装置における撮影条件設定法}

大车田市立病院放射線科

浜崎一義・江崎 友騎 小原 義晴

[目的〕

XTV 撮影において，自動制御装置を用いるとき，一 定濃度の写真を得る。

[笑験]

(1)愿さを一定としたとさ, 管電圧, 管電流の変化によ る濃度の変化、(2)管電压・管電流を一定としたとき，厚 さの変化による濃度の変化. (3)(1)(2)時の撮影時間の変 化. (4)(1)(2)時の入射線量の変化.

[結果]。

$\begin{array}{crr}7 \mathrm{~cm} \sim 12 \mathrm{~cm} & 50 \mathrm{~mA} & 80 \mathrm{kV} \\ 14 \mathrm{~cm} & 100 \mathrm{~mA} & 90 \mathrm{kV} \\ 16 \mathrm{~cm} \sim 18 \mathrm{~cm} & 200 \mathrm{~mA} & 90 \mathrm{kV} \\ 20 \mathrm{~cm} \sim 22 \mathrm{~cm} & 200 \mathrm{~mA} & 100 \mathrm{kV} \\ 23 \mathrm{~cm} \text { 以上 } & 200 \mathrm{~mA} & 110 \mathrm{kV}\end{array}$

20.シンチグラム開始時間の検討（第 2 報） - ${ }^{99 \mathrm{~m}}$ Tc-diphosphonate による骨シンチグラムにつ いて一

九州大学医学部附属病院放身線部 中野秀一郎・甫村 睦子・桜木 允雄 森 定義

${ }^{99 \mathrm{~m}} \mathrm{Tc}$-diphosphonateを $10 \mathrm{Cmi}$ 静注したのち経時的 に像を取り込み，集積状浣をミニコンピュータにより分 析し，骨シンチの撮像開始時間を検討した。

1) 同一部位，同一体位にて，腰椎，一腎孟，Back ground に関心領域（Roi）を設定し時間経過亡共にそれ ぞれの臓器によ゙のように集積されるかを見た。

2) Back ground に対する腎孟及び腰椎の Count 比 を求めることにより骨に效率よく集まる時間を求めた。

[結果]

6 例中 4 例は 3 時間までは Back ground に対する骨 の Count 比は上昇したがその後はほぼプラトーに達し た. 4〜10時間後ではほとんど変化を認めなかった。

21. アイントープ除染剂の比較

九州大学医学部附属病院放射線部 中野秀一郎・市村 睦子. 桜木 允雄 森 定義 